\title{
Restriction Mapping and Close Relationship of the DNA of Streptomyces erythraeus Phages 121 and SE-5
}

\author{
By RYSZARD BRZEZIǸSKI, *+ EWA SURMACZ, \\ MALGORZATA KUTNER AND ANDRZEJ PIEKAROWICZ \\ Institute of Microbiology, Warsaw University, Warsaw, Poland
}

(Received 12 December 1985; revised 2 May 1986)

The biological properties and genome structure of two actinophages, 121 and SE-5, infecting Streptomyces erythraeus were characterized. They had the same host range (limited to $S$. erythraeus) and similar DNA G + C contents (around $60 \mathrm{~mol} \%$ ). Restriction maps of their genomes also showed many similarities. The close relationship between the two phages was confirmed by DNA hybridization experiments: large parts of their genomes were homologous, except for a segment in the middle of the map, where no hybridization was detected.

\section{INTRODUCTION}

The actinophages 121 and SE-5 studied in this work are virulent phages able to lyse an industrially important strain, the erythromycin producer Streptomyces erythraeus. Phage 121 was described first by Retinskaya \& Rautenstein (1960) and further characterized, by Rautenstein \& Retinskaya (1963), together with three other phages infecting this Streptomyces species. All these phages were very similar in morphology, kinetics of inactivation by UV light, citrate sensitivity and serological properties. Five other actinophages (including SE-5), described by Ostrowska-Krysiak et al. (1971) and Ostrowska-Krysiak (1974), were serologically related to those studied by Rautenstein \& Retinskaya (1963): for example, antiserum against phage SE-5 also inactivated 121 particles. These phages differed mainly in their degree of virulence (reflected, for example, by plaque morphology and burst size) and in $S$. erythraeus strain specificity (some of the phages were able to lyse strains that were selected for resistance to another of the phages; Gurkau \& Ostrowska-Krysiak, 1972). Finally, in all the cases studied, the host range was limited to erythromycin-producing strains of $S$. erythraeus.

Here we present further evidence for a close relationship at the DNA level between two of these actinophages.

\section{METHODS}

Phages and micro-organisms. Streptomyces erythraeus 64-575 (Gurkau \& Ostrowska-Krysiak, 1972) was used as a host for phage amplification. Phage 121 was originally isolated from a lysogenic strain of $S$. erythraeus (Retinskaya \& Rautenstein, 1960). Phage SE-5 was isolated from a lysed, large-scale culture (Ostrowska-Krysiak, 1974). Both phages and Streptomyces strains were kindly provided by Drs B. Ostrowska-Krysiak and A. Bloniska (Institute of the Pharmaceutical Industry, Warsaw, Poland).

Media and culture conditions. For actinophage amplification and host strain propagation, a medium containing (per litre) $10 \mathrm{~g}$ yeast extract (Difco), $0.5 \mathrm{~g} \mathrm{~K}_{2} \mathrm{HPO}_{4}$ and $10 \mathrm{~g}$ glucose and adjusted to $\mathrm{pH} 6.5$ was used either as a liquid medium, or solidified with $0.8 \%$ or $1.5 \%(\mathrm{w} / \mathrm{v})$ Bacto agar.

For DNA extraction, phages were amplified in liquid medium as follows. Spores of S. erythraeus $64-575$ were suspended in liquid medium, briefly $(10 \mathrm{~min})$ heated at $55^{\circ} \mathrm{C}$ and inoculated into $100 \mathrm{ml}$ liquid medium. The culture was incubated at $30^{\circ} \mathrm{C}$ with vigorous shaking for $36 \mathrm{~h}$, after which it had reached late exponential phase.

† Present address: Département de biologie, Faculté des sciences, Université de Sherbrooke, Sherbrooke (Québec) J1K 2R1, Canada. 
Then, the culture was inoculated with actinophage suspension in phage buffer ( $50 \mathrm{~mm}$-Tris buffer, $\mathrm{pH} 8 \cdot 0,10 \mathrm{mM}$ $\mathrm{MgSO}_{4}$ ) containing 2-5 $\times 10^{9}$ p.f.u. After 30 min preadsorption, the culture was diluted with fresh medium up to 1 litre and incubated overnight at $30^{\circ} \mathrm{C}$ with vigorous shaking. Usually, complete lysis was observed. The titre was around $10^{10}$ p.f.u. $\mathrm{ml}^{-1}$. Mycelial debris were removed by low-speed centrifugation.

Phage particles were precipitated with $10 \%(\mathrm{w} / \mathrm{v})$ polyethylene glycol (Carbovax 8000 , Fisher) in the presence of $0.5 \mathrm{M}-\mathrm{NaCl}$ (Yamamoto et al., 1970). Purification was achieved by centrifugation in a $\mathrm{CsCl}$ step gradient followed by flotation of phage particles on a $\mathrm{CsCl}$ layer (Davies et al., 1980).

Biological properties. The host range was determined by plating up to $10^{8}$ p.f.u. on a lawn of the strain to be tested. Adsorption efficiencies were determined similarly, as described by Adams (1959): cells from the early exponential phase of growth (approx. $10^{7}$ c.f.u. $\mathrm{ml}^{-1}$ ) were infected with phage at low m.o.i. $(<0 \cdot 1)$ and incubated in medium supplemented with $1 \mathrm{~mm}-\mathrm{NaCl}$ and $1 \mathrm{mM}-\mathrm{Ca}\left(\mathrm{NO}_{3}\right)_{2}$ at $30^{\circ} \mathrm{C}$ with gentle shaking. After $30 \mathrm{~min}$ incubation, samples were centrifuged and tested for free phage titre.

DNA extraction and analysis. After dialysis of phage $\mathrm{CsCl}$ stocks against $10 \mathrm{~mm}$-Tris buffer, $\mathrm{pH} 8.0,10 \mathrm{~mm}-$ EDTA, DNA was purified by phenol-chloroform extraction. DNA was precipitated with ethanol, and was dried and dissolved in $\mathrm{H}_{2} \mathrm{O}$.

Restriction enzymes were used as recommended by the suppliers. DNA fragments were separated on $0 \cdot 7-1 \cdot 5 \%$ agarose gels or on $3 \cdot 5-10 \%$ polyacrylamide gels.

The $\mathrm{G}+\mathrm{C}$ content was estimated by determination of the thermal denaturation temperature (Mandel \& Marmur, 1968), and by UV spectroscopy (Ulitzur, 1972).

For hybridization analysis, DNA fragments, separated on agarose gels, were blotted onto Schleicher and Schuell nitrocellulose BA 85 sheets, according to Southern (1975), as modified by Smith \& Summers (1980). Prehybridization and hybridization were done at $42{ }^{\circ} \mathrm{C}$ in $50 \%(\mathrm{v} / \mathrm{v})$ formamide, $0.1 \%(\mathrm{w} / \mathrm{v}) \mathrm{SDS}, 0.9 \mathrm{M}-\mathrm{NaCl}$, $0.005 \mathrm{M}$-EDTA, $0.05 \mathrm{M}$-sodium phosphate buffer $\mathrm{pH} 7 \cdot 7$. Heparin $\left(500 \mu \mathrm{g} \mathrm{ml}^{-1}\right)$ was included for background control (Singh \& Jones, 1984). Final washing was done at $50^{\circ} \mathrm{C}$ in $0.1 \%$ (w/v) SDS, $0.018 \mathrm{M}-\mathrm{NaCl}, 10^{-4} \mathrm{M}-\mathrm{EDTA}$, $10^{-3} \mathrm{M}$-sodium phosphate buffer $\mathrm{pH} 7 \cdot 7$. For hybridization probes, we used nick translated DNA (Rigby et al., 1977) of total phage or restriction fragments separated on a low melting-point agarose (BRL) gel and purified on a NACS Pre-Pac column (BRL).

\section{RESULTS}

\section{Biological properties}

Phage 121 was isolated by Retinskaya \& Rautenstein (1960) as a virulent variant of a prophage present in a lysogenic erythromycin-producing strain, $S$. erythraeus 8594 . However, in our experiments, we did not observe the abundant secondary growth of mycelium in the phage plaque, as described by these authors. Instead, plaque morphology was identical with that described by Ostrowska-Krysiak et al. (1971). This difference is probably due to the choice of host strain, as the latter authors described different plaque morphologies for phage 121 on various indicator strains. The plaque morphology observed for phage SE-5 was the same as for phage 121 .

Both phages have a narrow host range. We failed to obtain plaques on the following strains: $S$. albus G., S. lividans 66, S. coelicolor A3(2), S. fradiae, $S$. vinaceus, $S$. azureus, $S$. parvulus, $S$. griseus, $S$. cattleya. In the case of $S$. fradiae and $S$. albus G., failure to act as hosts was correlated with the virtual absence of adsorption of phage 121 in conditions giving $92 \%$ adsorption to $S$. erythraeus.

\section{Estimation of the $G+C$ content of phage DNA}

By measurement of the melting temperature of 121 and SE-5 DNA we concluded that the $\mathrm{G}+\mathrm{C}$ content was 59 and $57.5 \mathrm{~mol} \%$ respectively. Slightly higher values were obtained by the spectrophotometric method: 62.5 and $59.5 \mathrm{~mol} \%$ respectively. These fall into the range of values found for Streptomyces phages (Lomovskaya et al., 1980) and are quite different from the G + C content of host DNA (around $70 \mathrm{~mol} \% \mathrm{G}+\mathrm{C}$ ).

\section{Genomic organization of phages 121 and $S E-5$}

Genome length, calculated as the sum of the restriction fragment lengths, is $41.9 \mathrm{~kb}$ for 121 DNA and $42 \cdot 2 \mathrm{~kb}$ for SE-5 DNA. Sizes of DNA fragments produced by $B g l \mathrm{II}, P v u I I, X b a \mathrm{I}, S a l \mathrm{I}$, $S s t \mathrm{II}$ and $S t u \mathrm{I}$ are shown in Fig. 1. Both phage DNAs contain cohesive ends. This was shown by the tendency of terminal fragments to associate to give a fragment of a length equal to the sum of the two fragments (Fig. 2). 


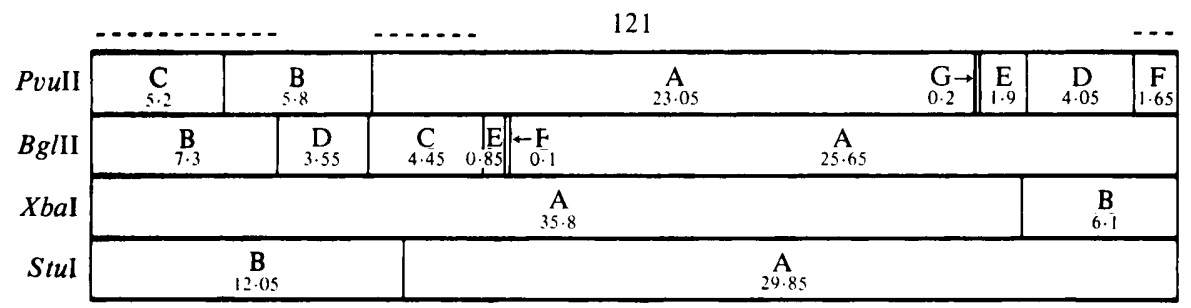

SE-5

\begin{tabular}{|c|c|c|c|c|c|c|c|c|}
\hline PvuII & $\underset{5.4}{\mathrm{D}}$ & $\underset{6.25}{\mathrm{C}}$ & & $\underset{11.5}{A}$ & $\mid \begin{array}{c}\mid G \\
1.35\end{array}$ & $\frac{B}{10.2}$ & $\left.\underset{0.2}{\mathrm{H}} \rightarrow\right|_{1.9} ^{\mathrm{F}}$ & $\underset{5.4}{E}$ \\
\hline$B g l I I$ & $\begin{array}{r}B \\
7.9 \\
\end{array}$ & $\underset{3.55}{\overline{\mathrm{E}}}$ & $\begin{array}{l}\mathrm{D} \\
3 \cdot 8 \\
\end{array}$ & $\begin{array}{rr}-\mathrm{H} & \mathrm{C} \\
0.1 & 6.8 \\
\end{array}$ & $\mathrm{~F}$ & \multicolumn{3}{|c|}{$\underset{18.1}{A}$} \\
\hline$X b a \mathrm{I}$ & \multicolumn{5}{|c|}{$\begin{array}{cc}A & \stackrel{1}{A} \\
26.4 & \underset{0.85}{G} \\
\end{array}$} & \multicolumn{2}{|c|}{$\begin{array}{c}\mathrm{B} \\
10.0 \\
\end{array}$} & $\underset{5.8}{\mathrm{C}}$ \\
\hline SalI & \multicolumn{4}{|c|}{$\underset{23.75}{\mathrm{~A}}$} & \begin{tabular}{c|c|}
$\mathrm{C} \rightarrow$ \\
.1
\end{tabular} & \multicolumn{3}{|c|}{$\begin{array}{c}\mathrm{B} \\
17.45 \\
\end{array}$} \\
\hline SstII & \multicolumn{5}{|c|}{$\underset{25.7}{A}$} & \multicolumn{3}{|c|}{$\underset{16.5}{B}$} \\
\hline
\end{tabular}

Fig. 1. Cleavage maps of 121 and SE-5 DNA. Sizes (kb) are mean values of at least four determinations. Larger fragments were determined indirectly (as a sum of smaller fragments created by double or triple digestions). In SE-5 DNA, the $5.4 \mathrm{~kb} P v u I I$ fragment localized on the left end of the map was arbitrarily assigned as D; the right-end PvuII fragment was assigned as E. Small fragments (less than $0.5 \mathrm{~kb}$ ) were identified on $5 \%$ acrylamide gels. All the other fragments were identified on $0.8-1.4 \%$ agarose gel. Dotted lines indicate areas of less intense hybridization.
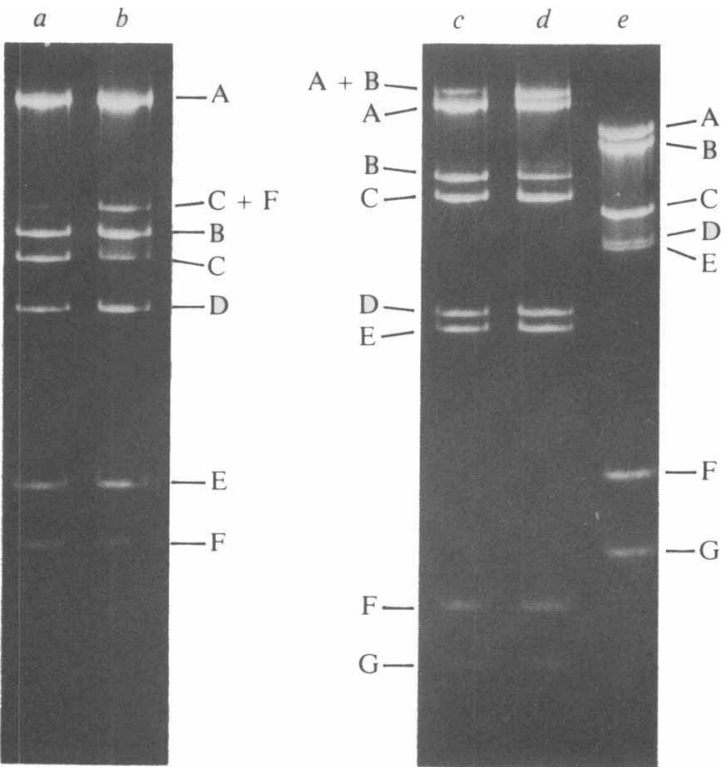

Fig. 2. Phage DNA (prepared as described in Methods) was digested with restriction endonucleases and either loaded directly on the gel (lanes $b$ and $d$ ) or heated for $5 \mathrm{~min}$ to $80{ }^{\circ} \mathrm{C}$ and quickly cooled on ice before loading (lanes $a, c$ and $e$ ). The samples were electrophoresed on a $1 \%$ agarose gel for $4 \mathrm{~h}$ at $90 \mathrm{~V}$. Lanes $a$ and $b, 121$ DNA digested with $B g l I I$; lanes $c$ and $d$, SE-5 DNA digested with $B g l$ II ; lane $e$, SE-5 DNA digested with PvuII. 
For the cleavage map of phage 121 DNA, the single $X b a I$ site was taken as a reference point. The $B g l \mathrm{II}$ map was deduced by combining the results of partial $B g l \mathrm{II}$ digestion and $B g l \mathrm{II}-\mathrm{XbaI}$ double digestion. The PvuII map was determined by partial digestion as well as by $B g l \mathrm{II}-\mathrm{P} v u \mathrm{II}$ and $X b a \mathrm{I}-P v u I I$ double digestions. Finally, the position of the single StuI site was deduced from double digestions. Sites for SalI and SstII are absent in 121 DNA.

In phage SE-5 DNA, the position of Sst II, SalI and $\mathrm{XbaI}$ sites was determined by single and double digestions. Double digestions with $B g l \mathrm{II}$ and one of the above enzymes located the $B g l \mathrm{II}$ fragments $\mathrm{A}$ and $\mathrm{F}$. The $B g l \mathrm{II}$ fragment $\mathrm{B}$ was identified as a terminal fragment (reduced intensity without heating and rapid cooling; Fig. 2, lanes $c$ and $d$ ). The PvuII map was deduced from double or triple digestions. However, from all these experiments, the position of BglII fragments C, D, E, G and H could not be established. Therefore, BglII fragments F and G were extracted from low melting-point agarose, nick-translated and used as hybridization probes for Southern blot analysis of DNA fragments from partial and total $B g / \mathrm{II}$ and $\mathrm{PvuII}$ digests of SE-5 DNA (one of the results is shown in part in Fig. 3, lanes 9,10). The following order of $B g l \mathrm{II}$ fragments could be derived: E-D-G-H-C-F (Fig. 1). SE-5 DNA contains no site for StuI. Among other enzymes examined but not used for mapping, EcoRI gave 14 fragments with 121 DNA and 17 with SE-5 DNA, BclI gave 16 and 13, ClaI gave 9 and 7 and HindIII gave 8 and 13 , respectively, while $H$ indII gave more than 25 fragments with DNA of both phages. Neither 121 nor SE-5 DNA contained sites for BamHI, XhoI, SphI, AhaIII NcoI and SacI.

\section{Cross hybridization between $121 \mathrm{DNA}$ and SE-5 DNA}

Since the restriction maps of the two phage DNAs show some similarities and since we detected many fragments of identical size when digesting 121 and SE-5 DNA with restriction enzymes that cut frequently, for example AluI and Sau3A (data not presented), Southern blotting experiments were done to test for cross-hybridization between the two DNA molecules. Restriction fragments of phage 121 DNA were separated on an agarose gel, transferred to nitrocellulose and probed with nick-translated SE-5 DNA (Fig. 3, lanes 1,2,3). Restriction fragments of phage SE-5 DNA, treated in the same way, were hybridized with labelled 121 DNA (Fig. 3, lanes 4, 5, 6, 7).

A high level of homology was detected, as almost all the restriction fragments gave a signal on the respective autoradiograms. However, two EcoRI fragments from 121 DNA (3.7 kb and 1.45 $\mathrm{kb}$ ) had a very low intensity on the autoradiogram (Fig. 3, lane 1). Similarly, one SE-5 EcoRI fragment $(3.5 \mathrm{~kb})$ had a low intensity and two others $(1.9 \mathrm{~kb}$ and $1.3 \mathrm{~kb})$ gave no signal at all on the blot (Fig. 3, lane 6). This allowed us to estimate the extent of non-homology to be 4-6 kb in length. Most of the non-homologous region should be localized in the middle of the genome, as three central restriction fragments in SE-5 DNA ( PvuII fragment G, SalI fragment C and BglII fragment $F$ ) gave no hybridization signal (Fig. 3, lanes 4, 5, 7). This was confirmed by using one of these fragments ( $B g l I I$ fragment $F$ ) as a probe. With SE-5 DNA, the fragments predicted from the SE-5 restriction map gave hybridization signals on the autoradiogram (Fig. 3, lanes 9, 10), while no signals were detected with 121 DNA restriction fragments (Fig. 3, lane 8).

Less intense hybridization was observed with some of the 121 DNA PvuII or BglII fragments when SE-5 was used as a probe; these fragments are indicated by filled pointers in Fig. 3 and by the dotted line over the 121 restriction map (Fig. 1). It was not clear whether these fragments indicated regions of low homology or of lower $\mathrm{G}+\mathrm{C}$ composition, or merely indicated nonuniform incorporation of label into the nick-translated probe.

\section{DISCUSSION}

Phages 121 and SE-5 are distinct from actinophages previously characterized (Lomovskaya et al., 1980; Walter et al., 1981; Cox \& Baltz, 1984; Anné et al., 1984, 1985; Ogata et al., 1985; Greene \& Goldberg, 1985), judging from the number of restriction enzyme cleavage sites and from cleavage maps (when available). Phages 121 and SE-5 have similar plaque morphology and behave similarly during growth experiments. Their close relationship has now been confirmed by DNA restriction mapping and Southern blot analysis; there is only one major difference between the genomes of 121 and SE-5 and the overall DNA homology is high. 
Genome structure of actinophages 121 and SE-5
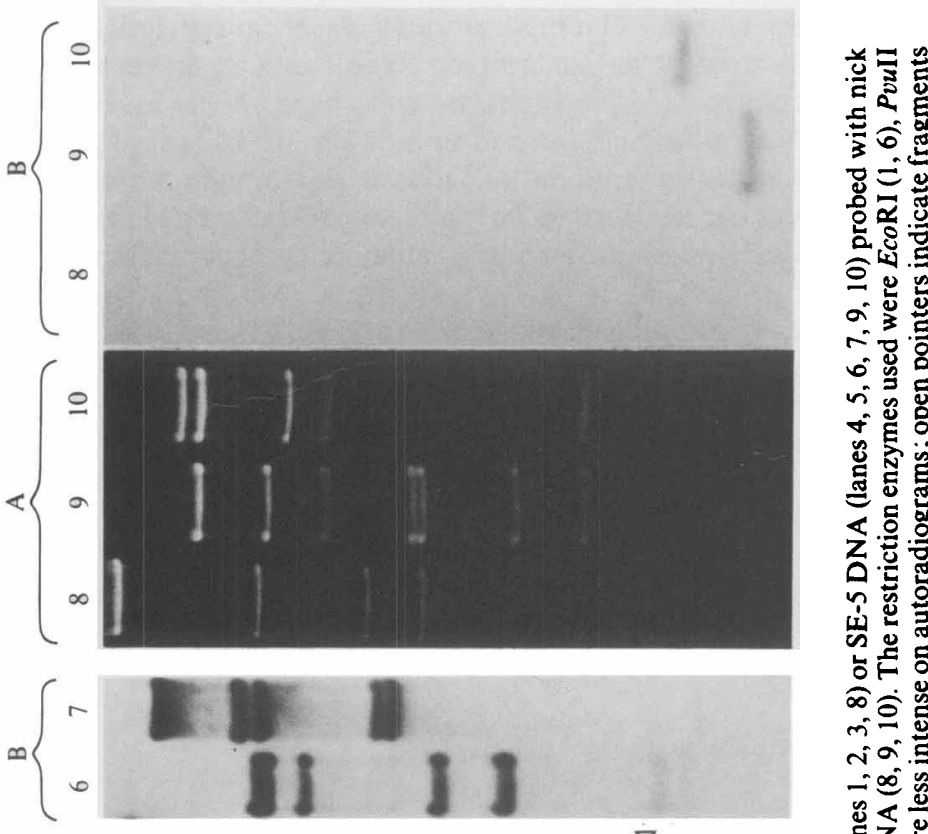

斻 के⿱宀⿻三丨口 No.

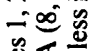

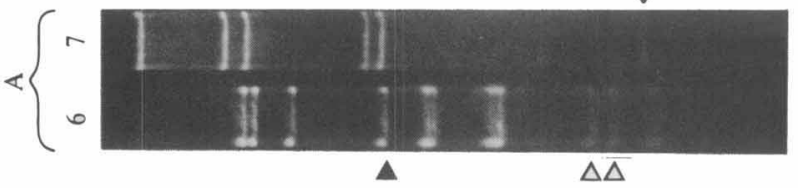

级

$<$ 可

之出

칭

空要
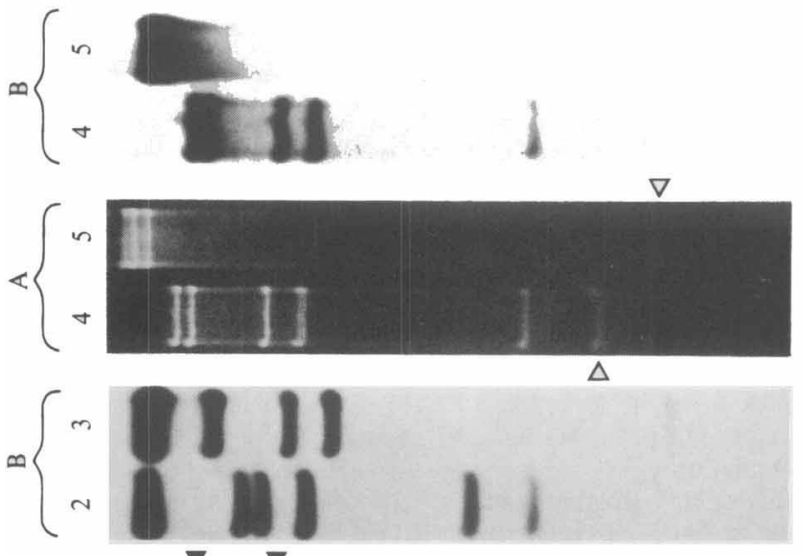

온

ब्र

氙.

.

5 은

동응

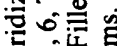
on 和可

죽

<是

전

楼

总施

刃ํㅇ을

岤哭

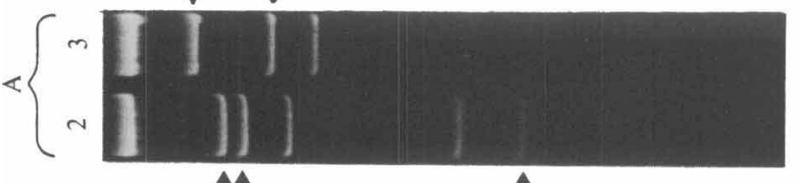

छ

通

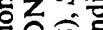

뭉

넝

을

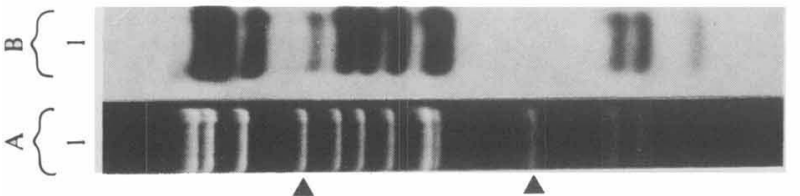

方

$\propto$ 宅

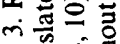

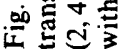


Phage 121 DNA is resistant to digestion by eight restriction enzymes among 19 tested. Of the eight restriction enzymes known to be present in Streptomyces species (Roberts, 1984), phage 121 is resistant to five. According to Cox \& Baltz (1984), such a pattern seems to be typical for broad host-range actinophages. This may indicate that phage 121 has evolved from a broad hostrange phage and that its adaptation to $S$. erythraeus as a sole host is a rather recent acquisition.

Phage SE-5 has a short central segment of DNA with a higher density of restriction target sites (mainly GC-rich sequences). It would be interesting to determine if this segment represents a 'module' (Botstein, 1980) originating from another phage genome or from a Streptomyces chromosome.

Our work extends previous findings (Rautenstein \& Retinskaya, 1963) that phages isolated on $S$. erythraeus as indicator strain have a narrow host range limited only to this species. This was indirectly confirmed by Cox \& Baltz (1984), who isolated and characterized many phages originating from soil samples and used $S$. fradiae and $S$. griseofuscus as hosts; although some of their phages had a very broad host range, none was able to lyse $S$. erythraeus. On the other hand, some broad host range phages that are able to amplify on $S$. erythraeus have been described, for example SH10 (Klaus et al., 1981), P23, CPC, CWK and CT (Anné et al., 1984). However, we have tested three of these phages (P23, CPC and CT) and they did not form plaques on $S$. erythraeus strains 64-575 or ISP 5517 (unpublished data). Therefore, the existence of broad host range $S$. erythraeus actinophages should be carefully reconsidered.

We thank Nicole Vanasse for expert secretarial assistance.

\section{REFERENCES}

ADAMS, M. H. (1959). Bacteriophages. London: Interscience Publications.

ANNÉ, J., WOHLlEben, W., BURKardT, H. J., SPRINGER, R. \& PÜHLER, A. (1984). Morphological and molecular characterization of several actinophages isolated from soil which lyse Streptomyces cattleya or S. venezuelae. Journal of General Microbiology 130, 2639-2649.

AnNé, J., Verheyen, P., Volckaert, G. \& Eyssen, H. (1985). A restriction endonuclease map of Streptomyces phage VWB. Molecular \& General Genetics 200, 506-507.

Botstein, D. (1980). A theory of modular evolution for bacteriophages. Annals of the New York Academy of Sciences 354, 484-491.

Cox, K. L. \& BALTZ, R. H. (1984). Restriction of bacteriophage plaque formation in Streptomyces spp. Journal of Bacteriology 159, 499-504.

DAVIS, R. W., Botstein, D. \& Roth, J. R. (1980). Advanced Bacterial Genetics. Cold Spring Harbor, NY: Cold Spring Harbor Laboratory.

GreENE, J. \& GoldberG, R. B. (1985). Isolation and preliminary characterization of lytic and lysogenic phages with wide host range within the Streptomycetes. Journal of General Microbiology 131, 24592465.

GurKaU, M. \& OSTROWSKA-KRYSIAK, B. (1972). Selection and characteristics of actinophage-resistant variants of Streptomyces erythraeus IA 64-575. Acta microbiologica polonica B4, 23-30.

Klaus, S., Krügel, H., Süss, F., Neigenfind, M., ZimmermanN, I. \& Taubeneck, U. (1981). Properties of the temperate actinophage SH10. Journal of General Microbiology 123, 269-279.

Lomovskaya, N. D., Chater, K. F. \& Mkrtumian, N. M. (1980). Genetics and molecular biology of Streptomyces bacteriophages. Microbiological Reviews 44, 206-229.
MANDEL, M. \& MARMUR, J. (1968). Use of ultraviolet absorbance-temperature profile for determining the guanine plus cytosine content of DNA. Methods in Enzymology 12B, 195-208.

Ogata, S., Suenaga, H. \& Hayashida, S. (1985). A temperate phage of Streptomyces azureus. Applied and Environmental Microbiology 49, 201-204.

OSTROWSKA-KRYSIAK, B. (1974). Some aspects of erythromycin biosynthesis. Postepy higieny $i$ medycyny doświadczalnej 28, 515-525.

OstrowsKa-Krysiak, B., GURKaU, M., SOKolowska, B., SikORA, D. \& BLOŇSKA, A. (1971). New variants of actinophages acting upon Streptomyces erythraeus. Acta microbiologica polonica B3, 195-201.

Rautenstein, YA. I. \& Retinskaya, V. I. (1963). Comparative study of the effect on Actinomyces erythreus of specific actinophages of varying virulence. Microbiology 32, 642-649.

Retinskaya, V. I. \& Rautenstein, YA. I. (1960). The lysogenicity of Actinomyces erythreus cultures and the isolation of their specific actinophages. Microbiology 29, 849-855.

Rigby, P. W. J., Dieckmann, M., Rhodes, C. \& Berg, P. (1977). Labelling deoxyribonucleic acid to high specific activity in vitro by nick translation with DNA polymerase I. Journal of Molecular Biology 113, 237-250.

ROBERTS, R. J. (1984). Restriction and modification enzymes and their recognition sequences. Nucleic Acids Research 12, r167-r196.

SINGH, L. \& JONES, K. W. (1984). The use of heparin as a simple cost-effective means of controlling background in nucleic acid hybridization procedures. Nucleic Acids Research 12, 5627-5638.

Smith, G. E. \& Summers, M. D. (1980). The bidirectional transfer of DNA and RNA to nitrocellulose or diazobenzyloxymethyl paper. Analytical Biochemistry 109, 123-129. 
Southern, E. M. (1975). Detection of specific sequences among DNA fragments separated by gel electrophoresis. Journal of Molecular Biology 98, 503-517.

ULITZUR, S. (1972). Rapid determination of DNA base composition by ultraviolet spectroscopy. Biochimica et biophysica acta 272, 1-11.

Walter, F., HartmanN, M. \& Klaus, S. (1981).
Restriction endonuclease analysis of DNA from the Streptomyces phages SH3, SH5, SH10 and SH13. Gene 13, 57-63.

Yamamoto, K. R., Alberts, B. M., Benzinger, R., LAWhORNe, L. \& Treiber, G. (1970). Rapid bacteriophage sedimentation in the presence of polyethylene glycol and its application to large-scale virus purification. Virology 40, 734-744. 